\title{
INDUSTRY 4.0 - AUTOMATION IN THE CONDITIONS OF ReConfiguration of Production Lines
}

\author{
Aleksandr Aryskin, Aleksey Grigoriev, Maksim Petrakov, Valentin Pryanichnikov, \\ Anastasia Travushkina \& Aleksander Travushkin
}
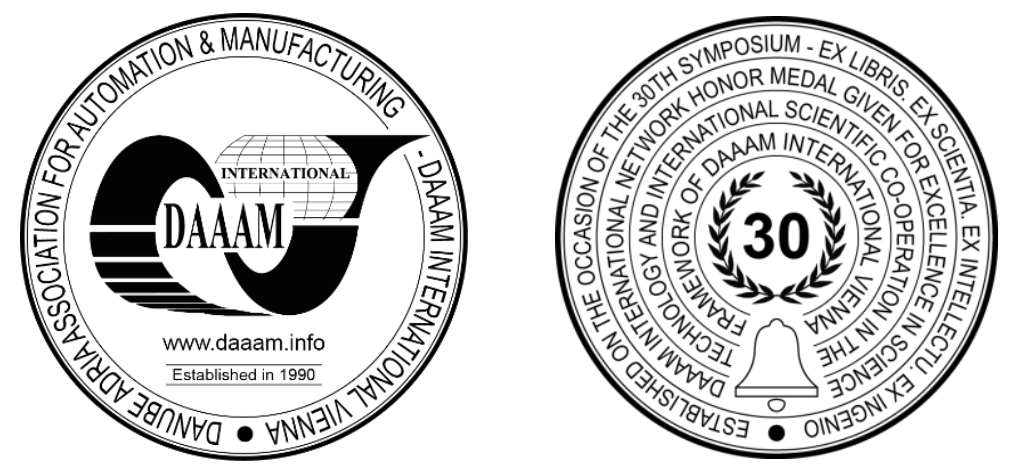

This Publication has to be referred as: Aryskin, A[lexander]; Grigoriev, A[leksey]; Petrakov, M[axim]; Pryanichnikov, V[alentin]; Travushkina, A[nastasia] \& Travushkin, A[leksandr] (2021). Industry 40 - Automation in the Conditions of Reconfiguration of Production Lines, Proceedings of the 32nd DAAAM International Symposium, pp.0660-0665, B. Katalinic (Ed.), Published by DAAAM International, ISBN 978-3-902734-33-4, ISSN 1726-9679, Vienna, Austria DOI: $10.2507 / 32$ nd.daaam.proceedings.093

\begin{abstract}
In the modern world, increasing digitalization of production processes is becoming more important for industry in order to increase the competitive advantages of manufactured products. Using the example of the company "Techfom", the practical implementation of the technology of "smart production" is presented, including such components as: digitalization of the main control elements; the use of remote access to the software being developed and to the production process itself; optimization of technological systems by digital means and architecture of software and hardware microprocessors and computer systems tied into a single local area network. By using various electromechanical elements in it (sensors, input devices, tachometers), a computing platform (operating system), a "network structure", a so-called cyberphysical system was created. Examples of the use of smart manufacturing components on specific complexes of the "Techfom" robotic industrial lines are shown and further tasks in their implementation are outlined to improve its productivity and product quality.
\end{abstract}

Keywords: Innovative material smart manufacturing; Industry 4.0; digitalization and cyberphysical systems; automation with digital twins; robotization.

\section{Introduction}

Reducing costs, improving the efficiency and competitiveness of products are the main areas of optimization of production and development of any enterprise. Currently, many companies are trying to implement the concept of Industry 4.0 at their production facilities and, thereby, are in search of new methods and approaches in the development and creation of their products.So, in China, the government has created five key national projects for the development and implementation of Industry 4.0 in the country's industry. Thanks to this policy, a large network of metallurgical enterprises Baosteel Group, engaged in technological research and development, has created a cloud business platform Ouyeel, which uses such aspects of "smart production" as the industrial Internet, big data and other modern technologies [1] Many global companies not only use innovative technologies to optimize their production, but also create such productions for customers. 
For example, Siemens, using elements of Industry 4.0 - the "Digital Twin" of production, the "Internet of Things" (IoT), "Big Data" - creates a continuous integrated process for its customers: "construction - technological preparation production" [2]. Some countries are realizing Industry 4.0 components not only in individual productions, but also creating special spaces. In Germany, the equivalent of "Silicon Valley" is a cluster called OWL (Intelligent Technical Systems OstWestfalenLippe). There are 173 companies on its territory, that implement the concept of "smart factories" in practice [3]. In Russia, basically, only large companies can realize Industry 4.0 technologies to increase their financial and economic indicators. For example, JSC Russian Railways uses a big data system, which makes it possible to predict the condition of train nodes, increase the degree of readiness of rolling stock [4].

The development and implementation of such technologies is considered in this article on the example of the creation of a robotic industrial line for the manufacture of products from innovative thermal and sound insulation material "Techfom" at one of the Moscow region enterprises. As noted, one of the approachers of Industry 4.0 is related with cyber-physical capabilities to ensure the connections of technical systems and society [5,6]. Using the example of the "Techfom" enterprise, one can see the practical implementation of the "smart production" technology, which includes such components as: digitalization of the main control elements and, as a result, the use of remote access to the software being developed and to the control process itself; optimization of technological systems by digital means, the choice of architecture of software and hardware microprocessor and computer systems united into a single local network.

The production process of innovative thermal and sound insulation material is carried out as follows: silicate block, water, chrysotile, salt, foaming agent are supplied to the input of the technological line. At the exit from it is the "Techfom" material, which has a different density (from 80 to $300 \mathrm{~kg} /$ cubic meter) and purpose (depending on the current dozens of formulations/recipes being executed), in addition, packed in polyethylene with fixed dimensions of 800x600x900 mm. The company "Techfom" has implemented cooking, mixing, drying and cutting complexes (production sites), which produce the corresponding technological processes shown in Figure 1. Consider the elements of "smart production" implemented in these production sites in more detail. "Digitalization" means not only the conversion of information into digital form from analog measured parameters (temperature, pressure, volume), but also the unification of data, coding, filtering to ensure the necessary sensor polling frequencies corresponding to the capabilities of receiving and processing their readings by microprocessors [7] and, most importantly, the logical analysis of hundreds of recipes, both current executable and newly created by the technologist.

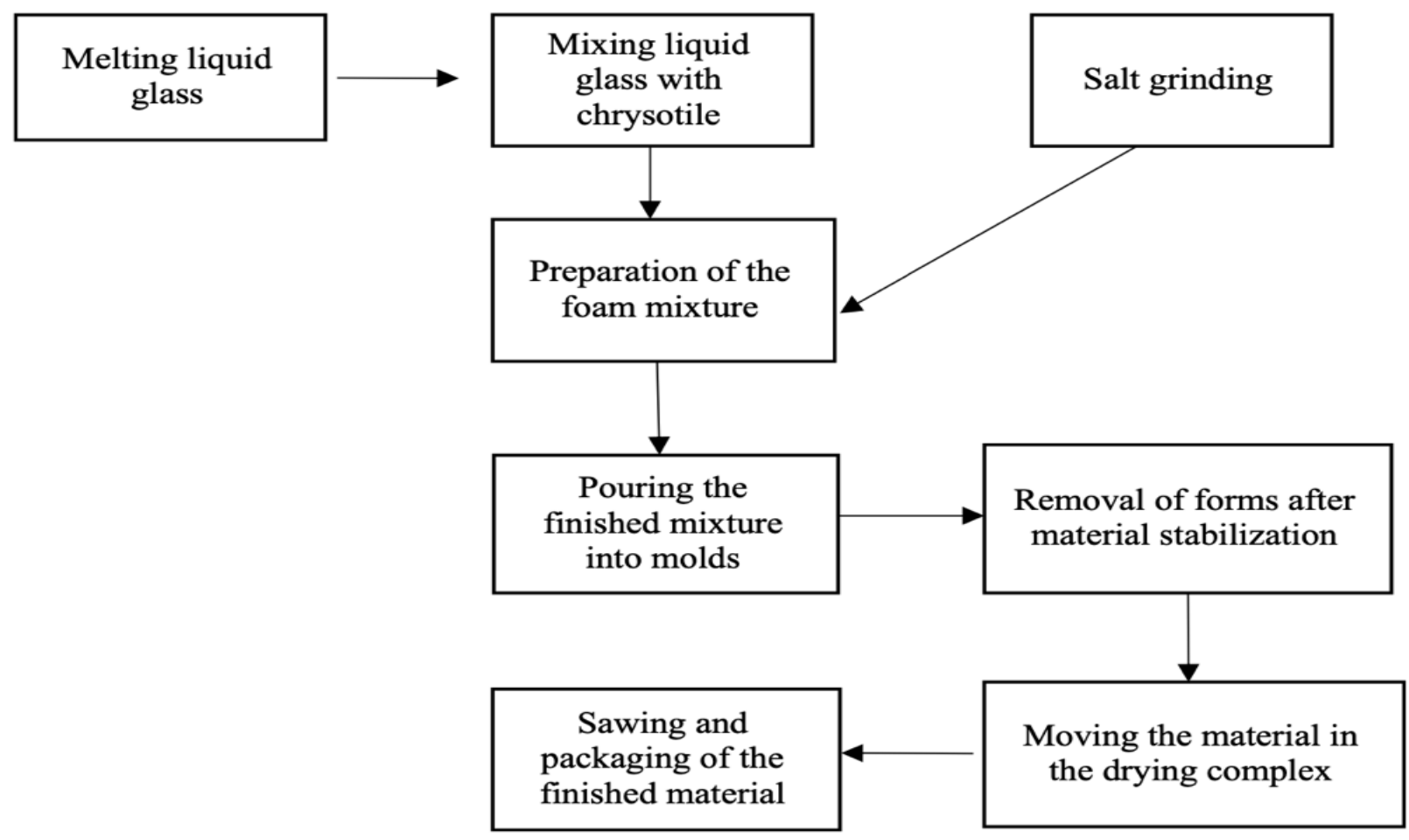

Fig. 1. The main technological processes of the flexible production line

The telemetry information received from the sensors is fed to the microprocessor control system, analyzed by it for issuing control commands and, according to the developed algorithm, transmitted to the actuators of the robotic industrial line (electric motors, relays, electric valves, gate valves). To control the trolleys (more than 60 pieces, each up to 2 tons) of the drying complex (Fig. 2), it is necessary to make their coordinated movement along the rail tracks, similar to a game of "tag". That is, it is possible to move a new trolley to one of the 4 drying lines only when the trolley at another end of the line is removed from this line to the driver line moving it in the transverse direction. 
Schematic diagram of the movement of platforms with the material of the Techfom

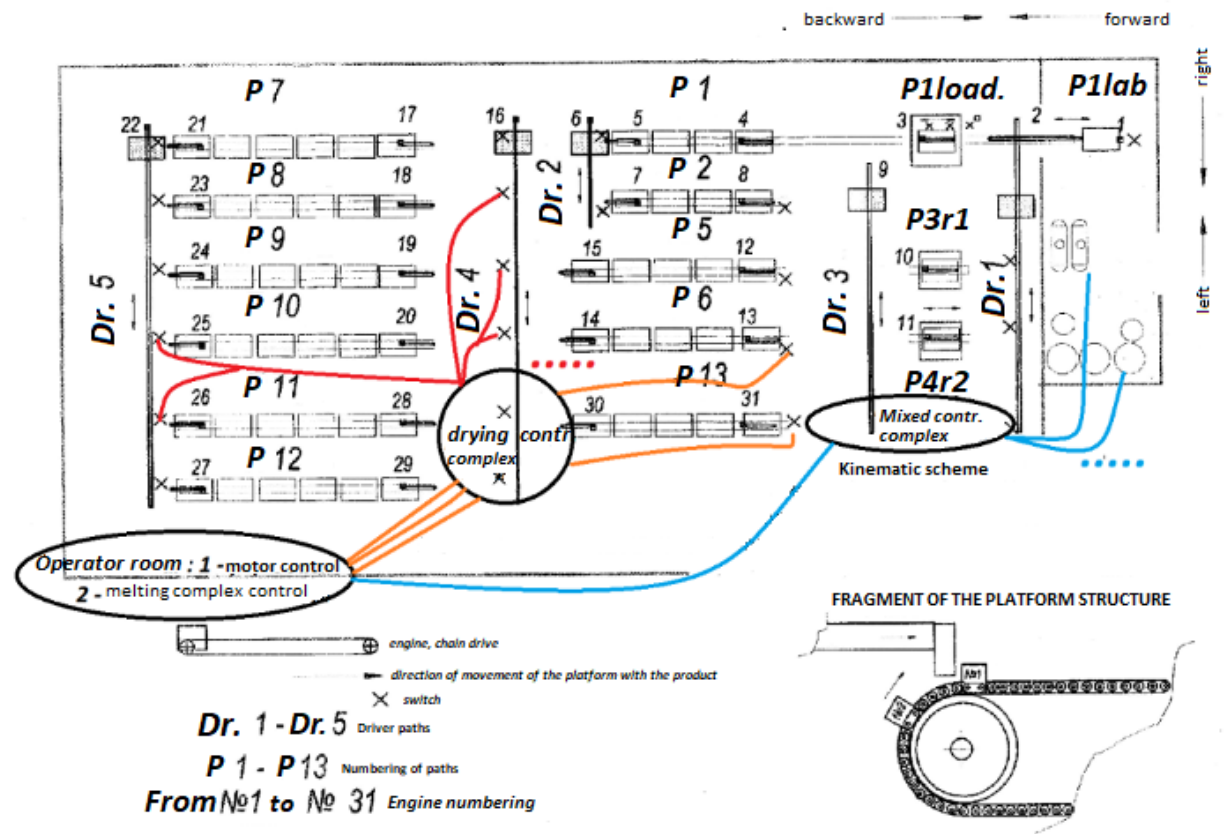

Fig. 2. The scheme of the lines of the drying complex

Therefore, any error in the control algorithm of switching on the motors, moving the trolleys, can lead to their falling off the rails, on which they move, and, as a consequence, to a technological accident at work. It is also important to obtain accurate telemetric information from the position sensors of these trolleys, which is embedded in their control algorithm. The main problem to be solved is to ensure the reliability of control due to the developed apparatus of logical analysis and comparison of the readings of large groups of sensors, which allows detecting abnormal situations even in conditions of failure of a small part of these sensors. The previously described production cycle control system has now received its expansion, modernization and additional application in the production of Techfom material, while the technology used allows modernization, improvements and changes without stopping production and in remote mode [8].

Tele-surveillance systems are also installed at the production site, which carry out tele-visual (and partially automated) control over the operation of mixing, drying and sawing complexes. This part of the "smart production" is one of the leading ones, since with the help of sensors and a tele-surveillance system, the operator monitors the production process remotely. The next criterion of smart production is end-to-end automation, which allows to improve and stabilize the quality of products, optimize the work of the entire enterprise, increase the quantity and volume of manufactured material.

Using various electromechanical elements (sensors, input devices), computing platforms (operating environment), a "network structure", a so-called cyberphysical system is created [9]. Control complexes with microcontrollers via transistor switches and intermediate relays, as well as sensors installed at all production sites, the information from which is converted by SCADA software and displayed on the operator and technologist's video monitors, are responsible for the process of "automation" in the production of innovative material "Techfom" (Fig. 3).

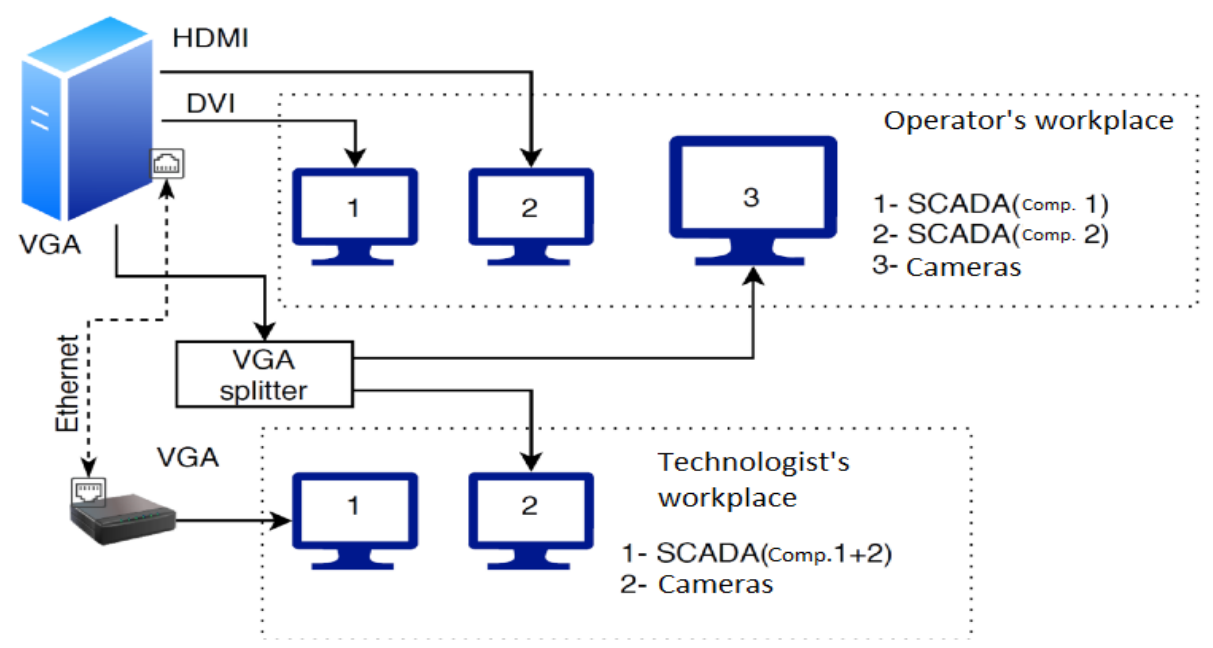

Fig. 3. Display of the received information for the operator and the technologist 
Automation is the main component of "smart production", thanks to which it is possible to realize the flow of almost individual orders, the productivity of the technological line increases significantly, using less human resources, as well as increasing the quality and volume of products [10]. During the Fourth Industrial Revolution (Industry 4.0), not only the production methods of the product have to be optimized, but also the interaction of man and machine are changing. Robots began to appear in many enterprises, thanks to which "robotization" has become one of the aspects of "smart production" [11]. Creating "intelligent robots" requires efficient software. With the help of it, it is possible not only to reduce the costs of "creating control programs", but also to ensure control over "service robots" [12]. At the considered production of the innovative material "Techfom", robotization is implemented by forming qualitative and quantitative parameters of the mixture of the material "Techfom" and subsequent control of transport and processes of displacement, filling of casting molds. This is carried out according to the characteristics set by the operator/technologist on the control computer and in the microprocessor control system, which monitors the required parameters of the manufactured mixtures using feedbacks from sensors installed on the cooking and mixing complexes (Fig. 4)

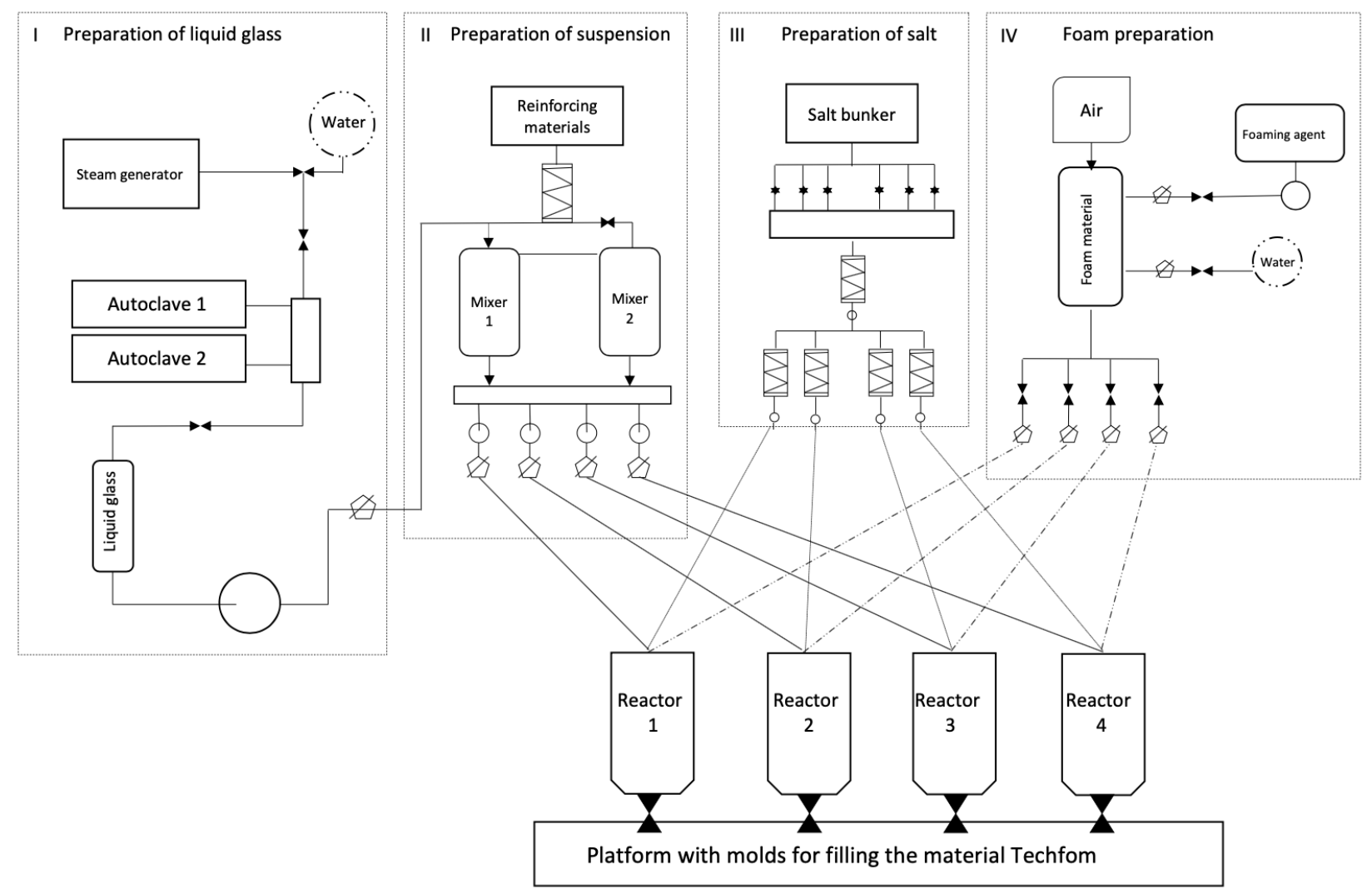

Fig. 4. Structure of technological interaction of the line complexes

In this case, robotization/ intellectualization is a subject of control based on feedbacks and ways of their logical verification due to algorithmic comparison of non-direct sensor readings. For example, when filling the container "Mixer 2" of complex II "Preparation of suspension" (Fig. 4), the liquid level is monitored in it using a conductometric level sensor placed in this container. But what happens if this sensor fails, or its contacts are oxidized, or the signal cable is broken? In these cases, in the absence of only a single simple feedback, a tank overflow may occur, which will lead to a technological accident at the enterprise. To solve this problem, it is necessary to implement processes consisting, for example, in the following program checks:

- IF a control signal is given to open the valve to fill the "Mixer 2" tank, and the readings of its level gauge do not change (in expected time), THEN it is necessary to issue a signal for additional verification and conclude, that either the valve is damaged or the level gauge does not work. Then an additional check is turned on - whether the liquid glass supply pump of complex I "Preparation of liquid glass" has worked.

- IF the pump is running, the valve is open, and the level gauge does not change its readings, THEN it is faulty and the operator must receive information about this on his video monitor for making subsequent decisions, and through the SCADA software it is necessary to stop the pump and turn off the valve.

So, a complete logical scheme of mutual influence/duplication of sensors and continuous testing of equipment directly during operation is compiled. For this purpose, a system of RULES (logical and expert conditions and appropriate crosschecks) is being created, which are implemented in the robotization of the technological line for the production of "Techfom" material. 
Smart production includes several aspects, one of which is the "digital twin of production". The digital twin is based on a model, that is created as an analogue of the physical production itself [13]. At the moment, there are various data collection systems, but it is difficult to find common applications to support them and practical examples of implementing digital twins with forecasting and contral capabilities [14]. Most often, the "digital twin" technology is used in aerospace and automotive companies, however, through the introduction of this methodology, it is possible to improve the financial and economic performance of companies operating in other sectors of the economy [15]. For this implementation of such technology, an effective data exchange is necessary, for which the "Techfom" company uses SCADA software tools to work out the technology for creating a component base of material, that differs in significant diversity both in density, composition and purpose:

- "Techfom - 80..120" with a density of $80 \ldots 120 \mathrm{~kg} /$ cubic meter can be used for insulation of residential premises;

- "Techfom - 120...150" with a density of $120 \ldots 150 \mathrm{~kg} /$ cubic meter can be used for noise reduction in residential/nonresidential premises;

- "Techfom - 150...220" with a density of $150 \ldots 220 \mathrm{~kg} /$ cubic meter can be used as structural elements of residential/non-residential premises (interior/inter-apartment partitions, enclosing structures /hinged panels).

The development of the technology for obtaining various types of "Techfom" material is carried out by the operator / technologist on the "digital twin" of production. This aspect of "smart production" allows using proper software to virtually work out the qualitative parameters of the required composition of the mixture for any customer, to assess the feasibility of the recipes. Thus, in this article, the implementation of a robotic industrial production line of products made of innovative material "Techfom" (based on the concept of Industry 4.0) was considered, thanks to this, costs are reduced, it becomes possible to increase the production capacity of the enterprise.

\section{Conclusion}

In this article, using the example of the "Techfom" enterprise, the practical implementation of the "smart production" technology is presented, including the digitalization of the main control elements and the use of remote access both to the software being developed and to the control process itself; optimization of technological systems by digital means, the choice of architecture of software and hardware microprocessor-computer systems united into a single local network. The use of various electromechanical elements (sensors, input devices, tachometers), a computing platform (operating environment) tied into a network structure actually led to the implementation of the so-called cyberphysical system. The article provides examples of the use of components of "smart production" on a specific complex of the robotic industrial line "Techfom", identifies further tasks of their implementation to improve productivity and quality of products. Thus, the application of the considered technology of digitalization of production processes leads to an increase in the competitive advantages of the products

\section{References}

[1] Goloventchik G.G, Yanhai He. (2021). New business models in digital globalisation of industry (China experience) Journal of the Belarusian State University Economics 2021;1:86-93 Russian

[2] V. Kishorre Annanth, M. Abinash \& Lokavarapu Bhaskara. (2021). Rao Intelligent manufacturing in the context of industry 4.0: A case study of siemens industry // Journal of Physics: Conference Series, 1969 (2021) 012019

[3] Novikov, S. V. (2020). Ekonomika izmerenij v usloviyah cifrovizacii / S.V. Novikov // Inzhenerno-fizicheskie problemy novoj tekhniki: Sbornik materialov XIV Vserossijskoj nauchno-tekhnicheskoj konferencii s mezhdunarodnym uchastiem, posvyashchyonnoj 85-letiyu so dnya rozhdeniya zasluzhennogo rabotnika VSH RF, doktora fiziko-matematicheskih nauk, professora M I Kiselyova, Moskva, 17-19 marta 2020 goda / Redkollegiya: A A Kransuckaya, E V Tumakova, E V Krechetova - Moskva: Obshchestvo s ogranichennoj otvetstvennost'yu «Diona», 2020 - S 236-242 (in Russian)

[4] Kapustina Larisa Mihajlovna, Kondratenko YUliya Nikolaevna. (2020). K voprosu o ponyatii «umnogo predpriyatiya» v cifrovoj ekonomike // Voprosy upravleniya 2020 №4 (65) Available from: https://cyberleninka ru/article/n/kvoprosu-o-ponyatii-umnogo-predpriyatiya-v-tsifrovoy-ekonomike (date of the application: 3009 2021, in Russian)

[5] Gribanov Yu I. (2019). Key aspects of the theory and methodology of digital transformation of social and economic systems / Gribanov Yu I // Vestnik Altajskoj akademii ekonomiki i prava - February 2019 - №2 (part 1) - P 8389

[6] Reiner A. (2014). Industrie 4.0 - Advanced Engineering of Smart Products and Smart Production // Technological Innovations in the Product Development 19th Intern Seminar on High Technology Piracicaba, Brasil, October 9th, 2014 Available from: https:/cyberleninka ru/article/n/kiberfizicheskaya-sistema-kak-razvitie-avtomatizatsii-navseh-etapah-zhiznennogo-tsikla-deyatelnosti-predpriyatiya-na-osnove (date of the application: 0209 2021)

[7] Khalin V. G., Chernova G. V. (2018). Digitalization and its impact on the Russian economy and society: advantages, challenges, threats and risks // Administrative Consulting 2018;(10):46-63 (In Russ) Available from: https://cyberleninka ru/article/n/tsifrovizatsiya-i-ee-vliyanie-na-rossiyskuyu-ekonomiku-i-obschestvo-preimuschestva-vyzovyugrozy-i-riski (date of the application: 0209 2021) 
[8] V. E. Pryanichnikov, A. A. Aryskin, S. R. Eprikov, K. B. Kirsanov, R. V. Khelemendik, A. Ya Ksenzenko, E. A. Prysev \& A. S. Travushkin (2017) Technology of Multi-Agent Control for Industrial Automation with Logical Processing of Contradictions, Proceedings of the 28th DAAAM International Symposium, pp 1202-1207, B Katalinic (Ed ), Published by DAAAM International, ISBN 978-3-902734-11-2, ISSN 1726-9679, Vienna, Austria, DOI: 10 2507/28th daaam proceedings 167

[9] Kudriavtceva A. S. (2019). Cyber-physical system as the development of automation processes at all stages of the life cycle of the enterprise through the introduction of digital technologies // SAEC 2019 №1

[10] Lu Y., Xu X., \& Wang L. (2020). Smart manufacturing process and system automation - A critical review of the standards and envisioned scenarios // Journal of Manufacturing Systems, 56, 312-325

[11] Dopico M., Gomez A., De la Fuente D., García N., Rosillo R., Puche J. (2016). A vision of industry 4.0 from an artificial intelligence point of view // International Conference on Artificial Intelligence (ICAI 2016 - WORLDCOMP 2016) Las Vegas, USA: CSREA Press; 2016 pp 407-413

[12] Eprikov, S.; Kim, V.; Pryanichnikov, V.; Prysev, E. \& Punenkov, O. (2019) Cloud Platform for Robotariums with Wireless Coverage Networks, Ensuring Service Robots with Parallel Simulation, Proceedings of the 30th DAAAM International Symposium, pp 1160-1165, B. Katalinic (Ed ), Published by DAAAM International, ISBN 978-3902734-22-8, ISSN 1726-9679, Vienna, Austria DOI: 10 2507/30th daaam proceedings 163

[13] Travushkina A. A. (2021). Obzor tekhnologii umnogo proizvodstva / A. A. Travushkina // Studencheskaya nauchnaya vesna: Vserossijskaya studencheskaya konferenciya: sbornik tezisov dokladov, Moskva, 01-30 aprelya 2021 goda - Moskva: Izdatel'skij dom "Nauchnaya biblioteka", 2021 - S 91-92 (in Russian)

[14] Alekseev, A.; Efremov, V.; Lyadskiy, D. \& Potekhin, V. (2020) Technical Implementation of Individual Elements of the Digital Twin Concept, B. Katalinic (Ed) Proceedings of the 31st DAAAM International Symposium, Vienna, Austria, pp 0254-0260

[15] Janda, P.; Hajicek, Z. \& Bernardin, P. (2019) Implementation of The Digital Twin Methodology, Proceedings of the 30th DAAAM International Symposium, pp 0533-0538, B. Katalinic (Ed), Published by DAAAM International, ISBN 978-3-902734-22-8, ISSN 1726-9679, Vienna, Austria, DOI: 10 2507/30th daaam proceedings 072 